\title{
Microbial Diversity and Proximate Composition of Tapai, A Sabah's Fermented Beverage
}

\author{
Chiang Y. W., Chye, F. Y.* and Mohd Ismail, A. \\ School of Food Science and Nutrition, Universiti Malaysia Sabah, Locked Bag 2073, \\ 88999 Kota Kinabalu, SABAH \\ E-mail: fychye@ums.edu.my
}

\begin{abstract}
Tapai is a well-known indigenous fermented alcoholic beverage among Kadazan-Dusun-Murut (KDM) ethnics during festive occasions and gatherings in East Malaysia. Unfortunately, very little research has been done on this beverage. The objective of this study was to identify functional microfloras involved in the production of tapai. Samples from local producers were obtained for microbiological and proximate analysis. The fermentation process was predominated by yeasts and lactic acid bacteria (LAB) with initial numbers (CFU/g) of $10^{5}$ and $10^{6}$, respectively, which gradually increased during the first 2 weeks fermentation but decreased thereafter. The yeasts were identified as Sacchromyces cerevisiae, Candida krusei, C. pelliculosa, C. guillermondii, C. magnoliae and Rhodotorula glutinis, whereas the LAB were Lactobacillus brevis, L. plantarum, L. collinoides and Pediococcus sp. Moulds and Enterobacteriaceae were only present during the first 2 days of fermentation. Acetic acid bacteria were not detected throughout the entire process. The $\mathrm{pH}$ of tapai declined slowly from 6.6 to 3.4 in 14 days, and then showed an increment to 4.0. On the other hand, titratable acidity (as \% lactic acid) increased from 0.06 to 0.86 in 10 days, and then decreased to 0.82 at the end of the fermentation process. Alcohol was produced and the content can reach as high as $12.3 \%$ after 3 weeks fermentation. Proximate composition analysis showed that the moisture content in the end product was $61.8 \pm 6.1 \%$ whereas ash, protein, fat and crude fiber (of dried samples) were $0.50 \pm 0.1 \%, 8.7 \pm 0.1 \%, 0.29 \pm 0.01 \%$ and $0.56 \pm 0.03 \%$, respectively.
\end{abstract}

Keywords: Microflora, Indigenous, Fermented beverage, Malaysia

\section{INTRODUCTION}

Indigenous fermented foods have become a new interest and consequently provided new subjects for intellectual creation these few years. While traditionally produced food products may be of health concern to non traditional consumers due to the therapeutic properties of fermented food reported, advanced scientific knowledge on food fermentation and its microbial agent has increasingly revealed many beneficial effects which lead to new applications other than food preservation, safety and sensory appreciation. Many studies have been done on indigenous fermented foods from around the world (Tamang and Thapa, 2004; Sefa-Dedeh et al., 2004; Mugula et al., 2003; Muyanja et al., 2002; Leisner et al., 2001; Omafuvbe et al., 2000; Wacher et al. 2000) and information on microbiological, biochemical and nutritional changes during fermentation is well documented. Moreover, products like Indonesian tempe and Oriental soy sauce are well known indigenous fermented foods that have industrialized and marketed globally years ago (Wood, 1994).

Tapai is a well-known indigenous fermented alcoholic beverage among the Kadazan-Dusun-Murut (KDM) ethnic group of Sabah during festive occasions and gatherings. Unlike tapai in other Southeast Asia countries like tape ketan (Indonesia), tapai (Peninsular Malaysia, Singapore and Brunei), basi (Philipines) and Khao-mak (Thailand)

*Corresponding author
(Campbell-Platt, 2000) which are prepared as a food, Sabah's tapai is prepared as an alcoholic beverage. It has an alcoholic aroma with combination of sweet-sour-bitter taste and sometimes sparkling feel. Tapai is made from glutinous rice with sasad as starter culture although rice, cassava, pineapples and maize can be used as substitute for glutinous rice in some part of Sabah. During preparation of tapai, glutinous rice is cleaned and washed before cooked. Cooked glutinous rice is then spread for cooling in an open surface $\left(\approx 30^{\circ} \mathrm{C}\right)$. Starter culture cakes are grinded into powder and approximately $1.0-1.5 \%$ (by weight) is sprinkled on the cooled glutinous rice followed by mixing thoroughly using a wooden scoop. The mixture is transferred into tajau (earthen jar) and left open for 1 day before the lid of tajau is sealed. Good quality and matured tapai undergoes 3 weeks fermentation. There are few ways to consume tapai. The most popular way is by drinking hing or lihing (wine must). Tapai can also be consumed as kinomulok (fermented glutinous rice after the wine must have been separated) and linutau (water extract from kinomulok). Siopon or Sisopon is a way of consumption where a thin bamboo straw is inserted into water added kinomol (fermented glutinous rice in tajau) for sipping tapai extracts. Other than that, Montoku and talak (distilled wine must) are famous alcoholics beverage among KDM.

Unfortunately at present, there is no adequate information on the spectrum of microorganisms associated with tapai fermentation in Sabah as 
information on indigenous fermented food is extremely rare although this knowledge is essential for the development of this product with improved quality for commercial production and marketing. Thus, the objective of this research was to identify functional microfloras involved in the microbiological, biochemical and nutritional changes that took place during tapai production.

\section{MATERIALS AND METHODS}

\section{Enumeration, isolation and identification}

Freshly inoculated glutinous rice in tajau were purchased from a local tapai producer in Kampung Karanaan, Tambunan, Sabah and transported to the Food Microbiology Laboratory of the School of Food Science and Nutrition at University Malaysia Sabah for immediate microbial analysis. Twenty five grams of samples were homogenized with $225 \mathrm{ml}$ of Quarter Strength Ringer's Solution (Merck, Germany) in a Bag Mixer (Interscience, France) for 30 min and serially diluted in the same diluent in duplicate. During tapai fermentation, the same amount of sample was collected from the tajau for microbial analysis every 2 successive days for 20 days. Yeast and mould counts were determined using Dichloran Rose Bengal Choramphenicol (DRBC) Agar (Merck, Germany) (Ardhana \& Fleet, 2003) and incubated at $25^{\circ} \mathrm{C}$ for 3 days. Lactic acid bacteria (LAB) were enumerated in M17 Agar (Merck, Germany) aerobically and on de Man Rogosa and Sharpe (MRS) Agar (Merck, Germany) anaerobically (Oxoid Carbon Dioxide System BR 39, England) at $30^{\circ} \mathrm{C}$ for 2 days (Mugula et al., 2003). Acetic acid bacteria were enumerated using Glucose Yeast Extract Calcium Carbonate Agar (glucose $5 \%$, yeast extract $1 \%$, calcium carbonate $3 \%$ and agar $2 \%$ ) and incubated at $30^{\circ} \mathrm{C}$ for 6 days (Du Toit and Lambrechts, 2002). Enterobacteriaceae and aerobic mesophilic count was determined using Violet Red Bile Glucose Agar and Plate Count Agar (Merck, Germany) (Thapa and Tamang, 2004) at $37^{\circ} \mathrm{C}$ for 2 days, respectively.

About 10-15 colonies were selected randomly from the plates. Purity of the isolates was checked by streaking again on fresh agar plates of the isolation medium. Yeasts and $\mathrm{LAB}$ isolates were stored at Potato Dextrose Agar (Merck, Germany) and MRS Agar slants, respectively. Yeasts were identified according to their cell morphology, physiological, carbon sources assimilation and fermentation patterns described by Kurtzman and Fell (1998) supplemented with API 20C AUX test strips (BioMérieux, France). LAB were identified according to cell and colony morphology, Gram and catalase reactions, gas production from glucose and fermentation pattern in API $50 \mathrm{CH}$ and API $50 \mathrm{CHL}$ Medium (BioMérieux, France).

\section{Analysis of proximate composition}

Ten grams sample of fermented glutinous rice was blended with $20 \mathrm{ml}$ of distilled water in a homogenizer for 30 seconds and the $\mathrm{pH}$ of the slurry was determined by digital $\mathrm{pH}$ meter calibrated with standard buffer solutions (Merck, Germany). Titratable acidity (expressed as percent lactic acid) of tapai was determined by titrating the filtrates, a well blended $10 \mathrm{~g}$ sample in $90 \mathrm{ml}$ distilled water with $0.1 \mathrm{~N}$ sodium hydroxide to end point using phenolphthalein as indicator. Alcohol content was determined by blending $10 \mathrm{~g}$ sample with $90 \mathrm{ml}$ distilled water in the homogenizer described above using distillation method.

The moisture content was determined by drying samples in oven for overnight at $70^{\circ} \mathrm{C}$ to constant weight. Ash content was determined by heating the dried end product in furnace at $550^{\circ} \mathrm{C}$ overnight till the difference between two successive weighing was not more than $0.1 \%$. Protein and fat contents were determined using Kjeldahl distillation method and Soxhlet method on dried sample respectively. For crude fiber content, $2 \mathrm{~g}$ sample was boiled for 30 minutes in $12.5 \%$ sulfuric acid, filtered and washed with hot distilled water untill no longer acidic before boiling in $12.5 \%$ sodium hydroxide and the same procedure repeated except it was filtered through a Gooch crucible and washed till no longer alkaline. Crucible with its content was dried at $100^{\circ} \mathrm{C}$, transferred into the incinerator oven and heated at $550^{\circ} \mathrm{C}$ overnight till the difference between two successive weighing was not more than $0.1 \%$. Crude fiber content was estimated by calculating percentage of weight loss in the sample. Carbohydrate content of sample was estimated by difference: $100-(\%$ moisture + \%protein + \%fat + \%ash + $\%$ fiber) (Nitisewojo, 1995). The determinations were done in triplicates and the mean values recorded.

\section{RESULTS AND DISCUSSION}

\section{Microorganisms}

Tapai fermentation was predominated by yeast and LAB as they were present from day 0 to day 20. Yeasts and moulds grew to $8.0 \log \mathrm{CFU} / \mathrm{g}$ on the $4^{\text {th }}$ day of fermentation from $5.1 \mathrm{log} \mathrm{CFU} / \mathrm{g}$ but the population of yeast population declined gradually thereafter until $6.1 \mathrm{log}$ $\mathrm{CFU} / \mathrm{g}$. However, moulds were undetected on the $5^{\text {th }}$ day onwards (Figure. 1). The population of LAB with $6.1 \mathrm{log}$ CFU/g initially became $1.0 \mathrm{log}$ CFU/g greater on the $4^{\text {th }}$ day and decreased to $5.1 \mathrm{log}$ CFU/g after 20 days. Acetic acid bacteria was not detected in all tapai samples. Enterobacteriaceae numbers declined from $4.6 \mathrm{log}$ CFU/g till an undetectable number within 4 days whereas aerobic mesophilies increased from $6.6 \mathrm{log} \mathrm{CFU} / \mathrm{g}$ to $8.4 \mathrm{log}$ $\mathrm{CFU} / \mathrm{g}$ in 2 days and decreased to $5.3 \mathrm{log} \mathrm{CFU} / \mathrm{g}$ at the end fermentation process.

Saccharomyces cerevisiae, Candida krusei, C. pelliculosa, C. glabrata, C. utilis, C. sphaerica, $C$. magnoliae, Rhodotorula mucilaginosa, $R$. glutinis and Cryptococcus laurentii were identified from among the yeasts isolated (Table 1). S. cerevisiae occurred in the highest number in tapai and was present at all stages of the fermentation. It has been isolated frequently from acidic fermentation of plant materials such as sourdough (Gobetti et al., 1994) and ogi (Nago et al., 1998). Thus, it 


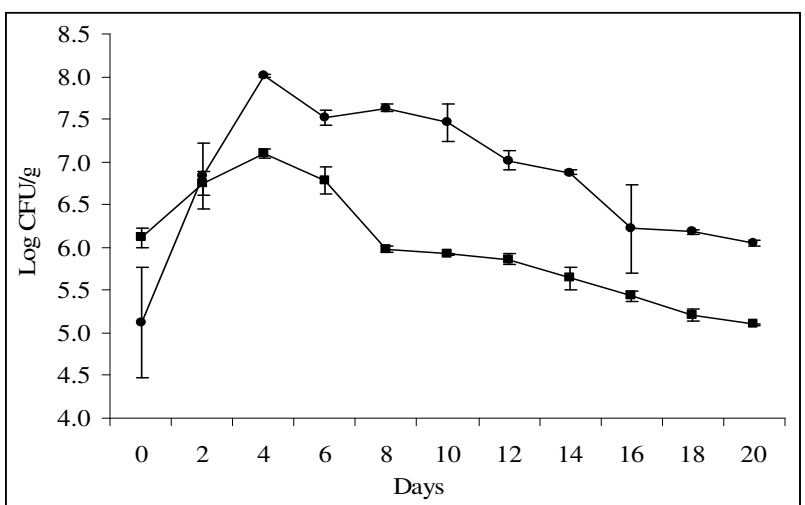

Figure 1: Growth of yeasts and moulds $(\bullet)$ and lactic acid bacteria ( $\mathbf{})$ during fermentation of tapai for 20 days.

has been suggested as playing a primary role in alcohol fermentation (Tsuyoshi et al., 2005). C. krusei, C. pelliculosa and C. glabrata were previously isolated from fufu (fermented cassava roots) (Oyewole, 2001), togwa (fermented sorghum, millet or finger millet) (Mugula et al., 2003) and kodo ko jaanr (alcoholic fermented finger millet beverage) (Thapa and Tamang, 2004), respectively and C. krusei has been associated with flavor and aroma of the end product of fufu (Oyewole, 2001). Saccharomyces and Candida species were reported capable of proliferating at low $\mathrm{pH}$ in porridge (Akinrele, 1970; Nout et al., 1989). C. utilis is known to produce a significant amount of ethyl acetate from biomass such as diluted sugar and ethanol. Ethyl acetate is recognised as an important flavour compound in wine and other grapederived alcoholic beverages. Such non-Saccharomyces yeast might contribute to flavour and aroma in the alcoholic beverages. C. sphaerica which was the anamorph state of $K$. lactis were isolated. $K$. lactis has found to be present in fermented dairy products such as cheese (Fadda et al., 2001) and is currently used for industrial applications for years as a source of $\beta$ galactosidase (Bolotin-Fukuhara et al., 2000). Unsurprisingly $C$. magnoliae was food spoilage yeast and it present may be due to contamination of the starter cake or utensil used during preparation as well as $R$. mucilaginosa and $R$. glutinis which were previously referred to as the species of common air contaminants or natural contaminants in cheese before they were stored (Viljoen and Greyling, 1995). Isolates not identified are due to inadequacy of the identification system used in the study and further investigation should be carried out. Though mould was only present in the early stage of fermentation, it was suspected to play a role in the degradation of glutinous rice into simpler substrate molecule to be utilized by yeast and LAB.

Eighty four percent strains of $L A B$ were nonsporeforming rods (Table 1). They were tentatively identified as Lactobacillus plantarum, $L$. brevis and $L$. paracasei subsp. paracasei but only $L$. plantarum and $L$. brevis showed predomination in the tapai fermentation process and were isolated from at stages of fermentation. $L$. plantarum have been isolated from several indigenous fermented foods including togwa (Mugula et al., 2003), tempoyak (fermented durian fruit pulp) (Leisner et al., 2001) and kule nato (fermented milk) (Mathara, 2004). It has been recognized as the dominant organism at the end of several natural lactic acid fermentations (Brauman et al., 1996; Kunene et al., 2000), probably due to its acid tolerance (Fleming and McFeters, 1981) and superior ability to utilize the substrates (Oyewole and Odunfa, 1990). L. brevis often occur in fermenting plant material (Corsetti et al., 2001) and have been isolated from

Table 1: Numbers of identified of yeast and lactic acid bacteria isolated from tapai fermentation

\begin{tabular}{|c|c|c|c|c|c|c|c|c|c|c|c|c|}
\hline \multirow[t]{2}{*}{ Species identified } & \multirow{2}{*}{$\begin{array}{c}\text { No. of } \\
\text { isolates }\end{array}$} & \multicolumn{11}{|c|}{ Days of isolation } \\
\hline & & 0 & 2 & 4 & 6 & 8 & 10 & 12 & 14 & 16 & 18 & 20 \\
\hline \multicolumn{13}{|l|}{ Yeast } \\
\hline Sacchromyces cerevisiae & 50 & 0 & 1 & 4 & 4 & 2 & 3 & 5 & 7 & 5 & 10 & 8 \\
\hline Candida krusei & 5 & 4 & 0 & 0 & 0 & 1 & 0 & 0 & 0 & 0 & 0 & 0 \\
\hline Candida pelliculosa & 18 & 0 & 5 & 3 & 1 & 2 & 3 & 1 & 2 & 0 & 0 & 1 \\
\hline Candida glabrata & 1 & 0 & 1 & 0 & 0 & $\overline{0}$ & 0 & 0 & 0 & 0 & 0 & 0 \\
\hline Candida utilis & 15 & 6 & 1 & 1 & 3 & 0 & 1 & 3 & 0 & 0 & 0 & 0 \\
\hline Candida sphaerica & 2 & 0 & 0 & 0 & 0 & 0 & 2 & 0 & 0 & 0 & 0 & 0 \\
\hline Candida. magnoliae & 2 & 0 & 0 & 1 & 0 & 0 & 0 & 0 & 0 & 1 & 0 & 0 \\
\hline Rhodotorula mucilaginosa & 1 & 0 & 0 & 1 & 0 & 0 & 0 & 0 & 0 & 0 & 0 & 0 \\
\hline Rhodotorula glutinis & 4 & 0 & 0 & 0 & 0 & 2 & 0 & 1 & 1 & 0 & 0 & 0 \\
\hline Cryptococcus laurentii & 1 & 0 & 0 & 0 & 0 & 1 & 0 & 0 & 0 & 0 & 0 & 0 \\
\hline Unidentified & 3 & 0 & 0 & 0 & 0 & 0 & 1 & 0 & 0 & 1 & 0 & 1 \\
\hline \multicolumn{13}{|l|}{ Lactic acid bacteria } \\
\hline Lactobacillus plantarum & 76 & 1 & 2 & 9 & 10 & 6 & 7 & 7 & 10 & 9 & 7 & 8 \\
\hline Lactobacillus brevis & 32 & 0 & 0 & 1 & 5 & 3 & 1 & 6 & 2 & 3 & 7 & 4 \\
\hline $\begin{array}{l}\text { Lactobacillus paracasei subsp. } \\
\text { paracasei }\end{array}$ & 4 & 2 & 0 & 0 & 0 & 0 & 2 & 0 & 0 & 0 & 0 & 0 \\
\hline Pediococcus pentosaceus & 14 & 10 & 4 & 0 & 0 & 0 & 0 & 0 & 0 & 0 & 0 & 0 \\
\hline Lactococcus lactis subsp lactis & 6 & 2 & 4 & 0 & 0 & 0 & 0 & 0 & 0 & 0 & 0 & 0 \\
\hline
\end{tabular}


fermented foods like kenkey (fermented maize dough) (Halm et al., 1993), mawe (fermented maize dough) (Hounhouigan et al., 1993), and agbelima (fermented cassava dough) (Kofi et al., 1996). L. paracasei spp. paracasei has been reported to occur in boiled rice used to prepare som fak, a Thai fermented fish (Paludan-Müller et al., 1999). Sixteen percent of the LAB isolates were cocci and identified as Pediococcus pentosaceus and Lactococcus lactis subsp. lactis. Contrary to the report which showed domination of $P$. pentosaceus in the latter stage of corn dough fermentation (Nche et al., 1994), $P$. pentosaceus was only present in the early stages of fermentation, thus it seems that tapai fermentation is initiated by $P$. pentosaceus but finally dominated by $L$. plantarum as in the fermentation of mesu (fermented bamboo shoot) (Tamang and Sarkar, 1996). Similar to $P$. pentosaceus, Lactococcus lactis subsp. lactis were also only present in the early stages of fermentation correspond to the report by Muyanja et al. (2002) on bushera due to its inability to grow at lower $\mathrm{pH}$ as the tapai fermentation proceed.

A co-metabolism between yeasts and lactic acid bacteria has been suggested, whereby the bacteria provide the acid environment, which selects for the growth of yeasts and, the yeasts provide vitamins and other growth factors to the bacteria (Gobbetti et al., 1994; Steinkraus, 1996). Yeasts have also been reported to make a useful contribution to the improvement of flavour and acceptability of fermented cereal gruels (Banigo et al., 1974; Odunfa and Adeyele, 1985). Tapai is a safe fermented product to consume as no enterobacteriaceae were found at the end of the fermentation process, probably due to its low $\mathrm{pH}$, elevated titratable acidity and high alcohol content. Their disappearance may also be due to the presence of other antimicrobial compounds. The absence of acetic acid bacteria in tapai could be due to the sealed earthen jar which provide unsuitable growth condition as they as strictly aerobic bacteria.

\section{Proximate composition}

The $\mathrm{pH}$ of inoculated glutinous rice was 6.6 initially and it decreased rapidly and stabled steadily at 3.4 on the $15^{\text {th }}$ day. It increased to 4.0 at the end of fermentation. This may be due to the increased of titratable acidity (expressed as percent of lactic acid) from 0.06 to $0.86 \%$ in 10 days, and decreased to $0.82 \%$ in the end of tapai fermentation (Figure 2). The correlation between acidity and $\mathrm{pH}$ is believed to be associated with both yeasts and $L A B$ as $L A B$ were well known for production of acids especially lactic whereas some yeasts were previously reported to produce acid in alcohol fermentation to make a positive contribution to the products' flavour (Fleet, 2003). At the same time, low $\mathrm{pH}$ and high acidity also eliminated enteropathogen, coliforms and spoilage organisms in this product.

Meanwhile, its alcohol content increased day by day and was as high as $12.3 \%(\mathrm{v} / \mathrm{v})$ after 20 days fermentation (Figure 3). Yeasts may produce alcohol; however, Lactobacillus species have also been reported to produce

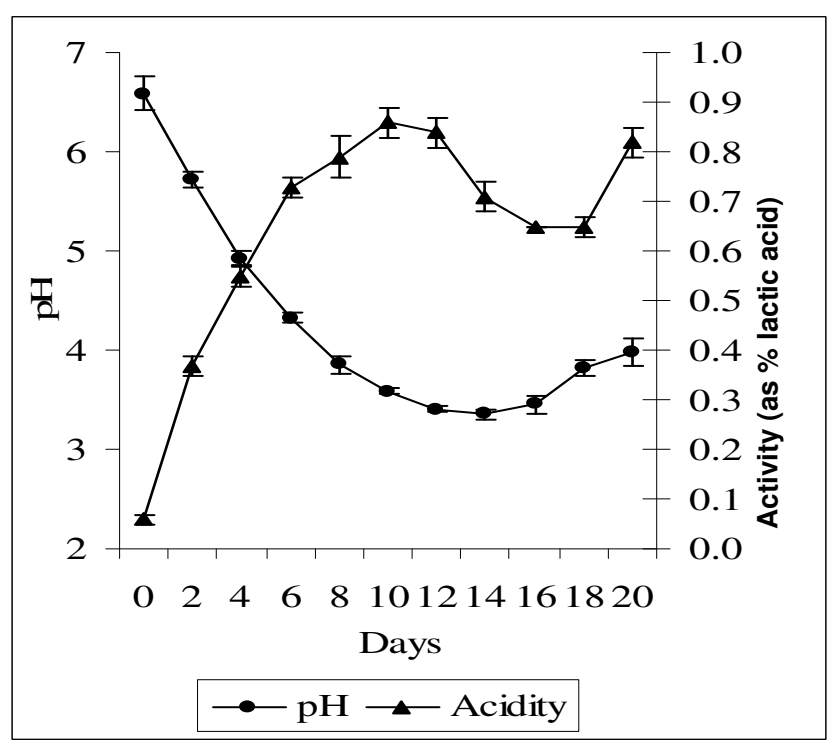

Figure 2: Changes of $\mathrm{pH}$ and acidity during tapai fermentation

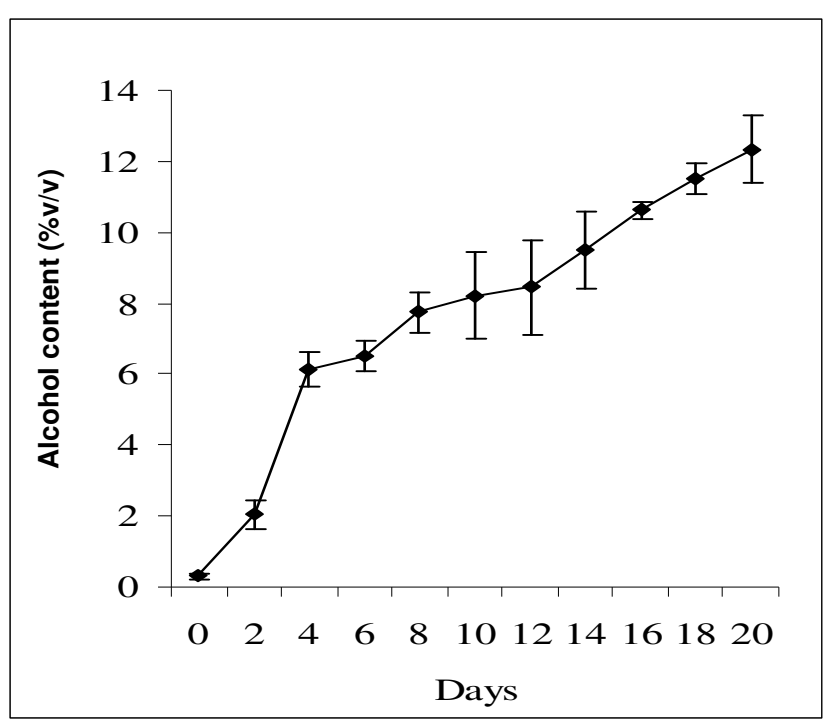

Figure 3: Alcohol content in tapai during fermentation.

ethanol. Alcohols produced play a role in helping to extract flavour components from fermenting substrates. Yeasts and $L A B$ also produce other volatile compounds such as malty flavored 2-methyl-propanal. The flavors contributed by yeasts and $L A B$ yield unique fermented products appreciated by consumers which were much different from the unfermented substrate.

The moisture and ash contents in the end product of tapai fermentation were $61.8 \pm 6.1 \%$ and $0.2 \pm 0.041 \%$ respectively. Crude protein, crude fat and crude fiber (of dried samples) were $3.3 \pm 0.04 \%, 0.1 \pm 0.004 \%$ and 
$0.2 \pm 0.01 \%$, respectively. The estimated carbohydrate content in tapai was $34.3 \pm 0.04 \%$. Because of its high calorie, tapai were not only consumed in festive occasions and gatherings, but also by ailing persons and post natal women to regain strength. Tapai were also consumed as a family staple food by some ethnic groups in rural areas.

The result of this study indicated that tapai contains a variety of yeasts and LAB. Various flavor compounds were believed present in tapai making it a favorite alcoholic beverage by Sabah peoples. Thus, controlled fermentation should be done to assess contribution of yeasts and LAB on flavor and aroma of this traditional alcoholic fermented beverage. There is a need for investigation into the selection of the most suitable strain for better controlled tapai fermentation. Starter cultures development is important for the potential small-scale commercial production of tapai and for improvement of its acceptability, microbiological stability and hygiene safety. Detail avaibility of nutrient values which included minerals and vitamins in tapai should be carried out. Strains isolated from tapai could be screened for their properties of exo- and endocellular enzymatic activities as well as potential probiotic and nutraceutical properties for application in improvement of human health.

\section{REFERENCES}

Akinrele, I.A. (1970). Fermentation studies on maize during the preparation of a traditional African starchcake food. Journal of Science and Food Agricutural. 21: 619-625.

Ardhana, M.M. and Fleet, G.H. (2003). The microbial ecology of cocoa bean fermentation in Indonesia. International Journal of Food Microbiology 86: 87-99.

Banigo, E.O.I., deMan, J.M. and Duitschaever, C.L., (1974). Utilization of high-lysine corn for the manufacture of ogi using a new improved processing system. Cereal Chemistry 51: 559- 572.

Bolotin-Fukuhara, M., Toffano-Nioche, C., Artiguenave, F., Duchateau-Nguyen, G., Lemaire, M., Marmeisse, R., Montrocher, R., Robert, C., Termier, M., Wincker, P. and Wésolowski-Louvel, M. (2000). Genomic Exploration of the Hemiascomycetous Yeasts: 11. Kluyveromyces lactis. FEBS Letters 487: 66-70.

Brauman, A., Keleke, S., Malonga, M., Miambi, E. and Ampe, F. (1996). Microbiological and biochemical characterization of cassava retting, a traditional lactic acid fermentation for foo-foo (cassava flour) production. Applied Environmental Microbiology 62: 2854- 2858.

Campbell-Platt, G. (2000). Fermented Foods. In. Encyclopedia of Food Microbiology. Robinson, R.K., Batt, C.A. and Patel, P.D. (eds.). London: Academic Press. p.736-773.

Corsetti, A., Lavermicocca, P., Morea, M., Baruzzi, F., Tosti, N. and Gobbetti, M. (2001). Phenotypic and molecular identification and clustering of lactic acid bacteria and yeast from wheat (species Triticum durum and Triticum aestivum) sourdoughs of southern Italy. International Journal of Food Microbiology 64: 95- 104.

Du Toit, W.J. and Lambrechts, M.G. (2002). The enumeration and identification of acetic acid bacteria from South African red wine fermentations. International Journal of Food Microbiology 74: 57-64.

Fadda, M.E., Cosentino, S., Deplano, M. and Palmas, F. (2001). Yeast populations in Sardinian feta cheese. International Journal of Food Microbiology 69: 153156.

Fleet, G.H. (2003). Yeast interactions and wine flavor. International Journal of Food Microbiology 86: 11-22.

Fleming, H.P. and McFeters, R.F. (1981). Use of microbial cultures: vegetable products. Food Technology 35: 84.

Gobbetti, M., Corsetti, A. and Rossi, J. (1994). The sourdough microflora. Interactions between lactic acid bacteria and yeasts: metabolism of carbohydrates. Applied Microbiology Biotechnology 41: 456- 460.

Halm, M., Lillie, A., Sørensen, A. and Jakobsen, M. (1993). Microbiological and aromatic characteristics of fermented maize dough from kenkey production in Ghana. International Journal of Food Microbiology 19: 135- 143.

Hounhouigan, D.J., Nout, M.J.R., Nago, C.M., Houben, J.H. and Rombouts, F.M. (1993). Characterization and frequency distribution of species of lactic acid bacteria involved in the processing of mawe, a fermented maize dough from Benin. International Journal of Food Microbiology 18: 279- 287.

Kofi, W., Amoa-Awua, A. and Appoch, F.E. (1996). Lactic acid fermentation of cassava dough into agbelima. International Journal of Food Microbiology 31: 87- 98.

Kunene, N.F., Geornaras, I., von Holy, A. and Hastings, J.W. (2000). Characterization and determination of origin of lactic acid bacteria from a sorghum-based fermented food by analysis of soluble proteins and amplified fragment length polymorphism fingerprinting. Applied Environmental Microbiology 66: 1084-1092.

Kurtzman, C.P. and Fell, J.W. (1998). The Yeast, a taxonomy study. $4^{\text {th }}$ edition. Amsterdam: Elsevier Science Publisher.

Leisner, J.J., Vancanneyt, M., Rusul, G., Pot, B. Lefebvre, K., Fresi, A. and Tee, L.T. (2001). Identification of lactic acid bacteria constituting the predominating microflora in an acid-fermented condiment (tempoyak) popular in Malaysia. International Journal of Food Microbiology 63: 147157.

Mathara, J.M., Schillinger, U., Kutima, P.M., Mbugua, S.K. and Holzapfel, W.H. (2004). Isolation, identification and characterization of the dominant microorganisms of kule nato: the Maasai traditional fermented milk in Kenya. International Journal of Food Microbiology 94: 269-278.

Mugula, J.K., Nnko, S.A.M., Narvhus, J.A. and Sorhaug, T. (2003). Microbiological and fermentation characteristics of togwa, a Tanzanian fermented food. 
International Journal of Food Microbiology 80: 187199.

Muyanja, C.M.B.K., Narvhus, J.A., Treimo, J. and Langsrud, T. (2002). Isolation, characterization and identification of lactic acid bacteria from bushera: a Uganda traditional fermented beverage. International Journal of Food Microbiology 80: 201-210.

Nago, C.M., Hounhouigan, D.J., Akissoe, N., Zanou, E. and Mestres, C. (1998). Characterization of the Beninese traditional ogi, a fermented maize slurry: physiological and microbiological aspects. International Journal of Food Science Technology 33: 307-315.

Nche, P.F., Odamtten, G.T., Nout, M.J.R. and Rombout, F.M. (1994). Dry milling and accelerated fermentation of maize for industrialproduction of kenkey, a Ghanaian cereal food. Journal Cereal Science 20: 294- 298.

Nitisewojo, P. (1995). Prinsip Analisis Makanan. Bangi: Penerbit UKM.

Nout, M.J.R., Rombouts, F.M. and Havelaar, A., (1989) Effect of natural lactic fermentation of infant food ingredients on some pathogenic microorganisms. International Journal of Food Microbiology 8: 351361.

Odunfa, S.A. and Adeyele, S. (1985). Microbiological changes during the traditional production of ogi-baba, a West African fermented sorghum gruel. Journal of Cereal Science 3: 173-180.

Omafuvbe, B.O., Shonukan, O.O. and Abiose, S.H. (2000). Microbiological and biochemical changes in traditional fermentation of soybean for 'soy-daddawa'Nigerian food condiment. Food Microbiology 17: 469474.

Oyewole, O.B. (2001). Characteristics and significance of yeast' involvement in cassava fermentation for 'fufu' production. International Journal of Food Microbiology 65: 213-218.

Oyewole, O.B., (1997). Lactic fermented foods in Africa and their benefits. Food Control 8: 289-297.

Oyewole, O.B. and Odunfa, S.A., (1990). Characterisation and distribution of lactic acid bacteria in cassava fermentation during fufu production. Journal of Applied Bacteriology 68: 145152.
Paludan-Muller, C., Huss, H.H. and Gram, L. (1999). Characterisation of lactic bacteria isolated from a Thai low-salt fermented fish product and the role of garlic as substrate for fermentation. International Journal of Food Microbiology 46: 219- 229.

Sefa-Dedeh, S., Cornelius, B. Amoa-Awua, W. SakyiDawson, E. and Afoakwa, E.O. (2004). The microflora of fermented nixtamalized corn. International Journal of Food Microbiology 96: 97102.

Steinkraus, K.H., (1996). Handbook of Indigenous Fermented Foods. 2nd ed. New York: Marcel Dekker.

Tamang, J.P. and Sarkar, P.K. (1996). Microbiology of mesu, a traditional fermented bamboo shoot product. International Journal of Food Microbiology 29: 49-58.

Thapa, S. and Tamang, J.P. (2004). Product characterization of kodo ko jaanr: fermented finger millet beverage of the Himalayas. Food Microbiology 21: 617-622.

Tsuyoshi, N., Fudou, R., Yamanaka, S., Kozaki, M., Tamang, N., Thapa., S. and Tamang, J.P. (2005). Identification of yeast isolated from marcha in Sikkim, a microbial starter for amylolytic fermentation. International Journal of Food Microbiology 99: 135146.

Viljoen, B.C. and Greyling, T. (1995).Yeasts associated with Cheddar and Gouda making. International Journal of Food Microbiology. 28: 79 -88.

Wacher, C., Canas, A., Barzana, E. Lappe, P., Ulloa, M. and Owens, J.D. (2000). Microbiology of Indian and Mestizo pozol fermentations. Food Microbiology 17: 251-256.

Wood, B.J.B. (1994). Technology transfer and indigenous fermented foods. Food Research International 27: 269-280. 